Biol. Stud. 2011: 5(1); 57-68 • DOI: https://doi.org/10.30970/sbi.0501.136

www.http://publications.Inu.edu.ua/journals/index.php/biology

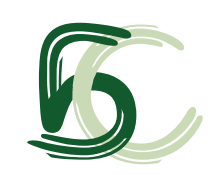

UDC 577.112.7:616

\title{
EFFECT OF HYPOXIA, GLUTAMINE AND GLUCOSE DEPRIVATION ON THE EXPRESSION OF MRNA OF THE RETINOBLASTOMA BINDING PROTEINS IN GLIOMA CELLS
}

\author{
D. O. Minchenko ${ }^{1,2,3}$, L. L. Karbovskyi', S. V. Danylovsky', M. Moenner ${ }^{3}$, O. H. Minchenko ${ }^{1,3}$ \\ ${ }^{1}$ Palladin Institute of Biochemistry, NAS of Ukraine, 9, Leontovych St., Kyiv 01601, Ukraine \\ ${ }^{2}$ O.O. Bohomoletz National Medical University, 13, Shevchenko Boulvd., Kyiv 01601, Ukraine \\ 3INSERM U920 Molecular Mechanisms of Angiogenesis Laboratory, \\ University Bordeaux 1, Talence, France \\ e-mail: ominchenko@yahoo.com
}

Hypoxia and ischemia, as well as endoplasmic reticulum stress, are principal factors which are necessary for tumor neovascularization and growth. We have studied the effect of blocking the endoplasmic reticulum - nuclei-1, the main signaling enzyme of stressing of the endoplasmic reticulum, on the expression of several retinoblastoma-related genes which play a significant role in the control of cell cycling, proliferation and apoptosis in glioma cell line U87. We have also studied the effect of hypoxia and ischemic conditions (glucose or glutamine deprivation) on the expression of these genes in control glioma cells and in subline of these cells with suppressed function of endoplasmic reticulum - nuclei-1 sensing and signaling enzyme. It was shown that blocking of endoplasmic reticulum - nuclei-1 signaling enzyme leads to increase in the expression levels of several retinoblastoma binding protein (RBBP) genes: RBBP2H1 (RDM5B), RBBP4 and RBBP8. Moreover, the expression levels of most of studied genes are significantly decreased under glucose or glutamine deprivation conditions both in control and endoplasmic reticulum - nuclei-1deficient glioma cells. However, the expression levels of RBBP2H1 and RBBP2 (RDM5A) mRNA are increased in glutamine deprivation conditions in both tested cell types. The expression levels of RBBP4, RBBP7 and RBBP8 are decreased but such levels of RBBP2 and $\mathrm{RBBP} 2 \mathrm{H} 1$ are increased in both tested cell types under the hypoxic conditions. Thus, the expression of most retinoblastoma-related genes is dependent on the endoplasmic reticulum - nuclei-1 signaling enzyme function in normal, hypoxic and ischaemic conditions.

Key words: mRNA expression, RBBP4, RBBP7, RBBP8, RBBP2, RBBP2H1, glioma cells, endoplasmic reticulum - nuclei-1, hypoxia, glucose and glutamine deprivation.

\section{INTRODUCTION}

Ischemia and hypoxia have been shown to induce a set of complex intracellular signaling events known as the unfolded protein response that is mediated by endoplasmic reticulum - nuclei-1 signaling enzyme (also named as inositol requiring enzyme-1alpha), 
to adapt cells for survival or, alternatively, to enter cell death programs through the endoplasmic reticulum-associated machineries [1-5]. As This enzyme participates in early cellular response to accumulation of misfolded proteins in the lumen of endoplasmic reticulum, occurring under both physiological and pathological conditions.

Two distinct catalytic domains of the bifunctional signaling enzyme endoplasmic reticulum - nuclei-1 were identified: serine/threonine kinase and endoribonuclease which contribute to endoplasmic reticulum - nuclei-1 signalling. The endoplasmic reticulum nuclei-1-associated kinase activity autophosphorylates and dimerizes this enzyme, leading to the activation of its endoribonuclease domain, degradation of a specific subset of mRNA and initiation of the pre-XBP1 (X-box binding protein 1) mRNA splicing [6-8]. Mature XBP1 mRNA splice variant encodes a transcription factor that has different Cterminus amino acid sequence and stimulates the expression of hundreds of unfolded protein response-specific genes [3, 9-11].

Recently, single mutations were detected in the endoplasmic reticulum - nuclei-1 gene of different human cancers and encoded by this gene enzyme was proposed as a major contributor to tumor (including glioblastoma) progression among protein kinases [12]. Moreover, the growing tumor requires the endoplasmic reticulum stress for its own neovascularization and growth, and the complete blocking of endoplasmic reticulum nuclei-1 signal transduction pathway had anti-tumor effects [13-15]. The endoplasmic reticulum stress response-signalling pathway is linked to the neovascularization process, tumor growth and differentiation, as well as cell death [16, 17].

Retinoblastoma proteins and family of retinoblastoma binding proteins participate in the control of cell cycle, proliferation and differentiation [18, 19]. The tumor suppressor protein retinoblastoma has been shown to interact with cyclin D1 protein, and the expression of cyclin D1 gene is regulated positively by retinoblastoma. This protein negatively regulates the G1-S transition by binding to the E2F transcription factors, until cyclin-dependent kinases phosphorylate retinoblastoma protein, causing E2F release. Moreover, retinoblastoma-E2F1 complex plays a critical role in ZBRK1 transcriptional repression, and loss of this repression may contribute to cellular sensitivity of DNA damage, ultimately leading to carcinogenesis [20]. Active E2F1/DP1 promotes apoptosis in both p53-dependent and independent manner, induces the expression of ADP rybosylation factor which, in turn, blocks MDM2-mediated ubiquination of p53, or enhances p53 transcriptional activity via direct binding of E2F1 to p53 [21].

The family of retinoblastoma binding or associated proteins participates in the control of cell cycle, proliferation and differentiation but have different function. The retinoblastoma binding protein-2 and $-2 \mathrm{H} 1$ are ubiquitously expressed nuclear proteins possessing lysine-specific demethylase activities (KDM5A and KDM5B) and exerting inhibitory effects towards multiple genes through direct interaction with their promoters [22]. Thus, PARP-1 regulates chromatin structure and transcription through a KDM5B-dependent pathway. The histone demethylase KDM5B is involved in the proliferation of cancer cells through the E2F/retinoblastoma pathway [23]. The retinoblastoma-binding protein-4 and -7 are present in protein complexes involved in histone acetylation and chromatin assembly, as well as they are a part of co-repressor complexes, which are an integral component of transcriptional silencing, and seem to be involved in transcriptional repression of E2Fresponsive genes. The retinoblastoma-binding protein-8 is a ubiquitously expressed nuclear protein and has DNA endonuclease activity [24]. It is also associated with BRCA1 and is thought to modulate functions of BRCA1 in transcription regulation, DNA repair, and/or cell cycle checkpoint control.

ISSN 1996-4536 • Біологічні Студії / Studia Biologica • 2011 • Том 5/№1 • С. 57-68 
We have studied the effect of hypoxia and glucose or glutamine deprivation on the expression of different genes coding for retinoblastoma binding proteins in glioma cell line U87 and modified glioma cells lacking activity of signaling enzyme endoplasmic reticulum - nuclei-1 for evaluation of retinoblastoma-dependent genes responsibility upon this signaling enzyme function under the hypoxic and ischemic conditions.

\section{MATERIALS AND METHODS}

Cell Lines and Culture Conditions. The glioma cell line U87 was obtained from ATCC (U.S.A.) and grown in high glucose (4.5 g/l) Dulbecco's modified Eagle's minimum essential medium (Gibco, Invitrogen, USA) supplemented with glutamine (2 mM), 10\% fetal bovine serum (Equitech-Bio,Inc., USA), penicillin (100 units/ml; Gibco) and streptomycin $\left(100 \mu \mathrm{g} / \mathrm{ml}\right.$; Gibco) at $37^{\circ} \mathrm{C}$ in a $5 \% \mathrm{CO}_{2}$ incubator. We used two sublines of this glioma cell line. One subline has suppressed both protein kinase and endoribonuclease activities of sensor endoplasmic reticulum - nuclei signaling enzyme-1 which was obtained by selection of stable transfected clones with overexpression of endoplasmic reticulum - nuclei-1 dominant/negative constructs (dnERN1) [13]. Second subline was obtained by selection of stable transfected clones with overexpression of vector, used for creation of dnERN1. This subline was considered as control 1.

Hypoxic conditions were created in special incubator with $3 \%$ oxygen and $5 \%$ carbon dioxide levels, and cultured cells were exposed for $16 \mathrm{hrs}$. For glucose or glutamine deprivation, the growing medium in culture plates was replaced on the medium lacking glucose or glutamine and exposed for $16 \mathrm{hrs}$.

RNA isolation. Total RNA was extracted from different tumor tissues and normal tissue counterparts by using Trizol reagent according to the manufacturer protocol (Invitrogen, U.S.A.) [25]. RNA pellets was washed with $75 \%$ ethanol and dissolved in nucleasefree water.

Reverse transcription and quantitative PCR analysis. The expression levels of cyclin retinoblastoma, retinoblastoma like-1, retinoblastoma associated protein RNF40 (ring finger protein 40), retinoblastoma associated protein EID1 (EP300 interacting inhibitor of differentiation 1), lysine-specific demethylase 5A and 5B (KDM5A and KDM5B; retinoblastoma binding protein-2 and $-2 \mathrm{H} 1$ ) and retinoblastoma binding proteins: $-4,-7$ and -8 (RBBP4, RBBP7 and RBBP8) mRNA were measured in glioma cell line U87 and its subline with a deficiency of endoplasmic reticulum - nuclei-1 by quantitative polymerase chain reaction of complementary DNA (cDNA) using „Stratagene Mx 3000P cycler” (U.S.A.) and SYBRGreen Mix (AB gene, Great Britain). QuaniTect Reverse Transcription Kit (QIAGEN, Germany) was used for cDNA synthesis as described previously [25]. Polymerase chain reaction was performed in triplicate.

For amplification of lysines-specific demethylase 5A (KDM5A; RBBP2), cDNA forward (5'-CAACGGAAAGGCACTCTCTC-3' and reverse (5'-CAAAGGCTTCTCGAGGTTTG-3') primers were used. The nucleotide sequences of these primers correspond to sequences 1204-1223 and 1420-1401 of human KDM5A cDNA (GenBank accession number NM_005056).

For amplification of lysines-specific demethylase 5B (KDM5B; RBBP2H1), cDNA forward (5'-GGTGAGCCAAAAACCTGGTA-3' and reverse (5'-AATCACAAACTCCCCAGCAC-3') primers were used. The nucleotide sequences of these primers correspond to sequences 1656-1675 and 1856-1937 of human KDM5B cDNA (GenBank accession number NM_006618). 
For amplification of retinoblastoma binding protein-4 (p48; RBBP4), cDNA forward (5'-GATGACCCATGCTCTGGAGT-3' and reverse (5'-CGCATCAAACTGAGCATCAT-3') primers were used. The nucleotide sequences of these primers correspond to sequences 264-283 and 444-425 of human RBBP4 cDNA (GenBank accession number NM_005610).

The amplification of retinoblastoma binding protein-7 (RBBP7; histone acetyltransferase type B subunit 2) cDNA forward (5'-TTCAGTGGCCCAGTCTTACC-3' and reverse (5'-CAGAACCAAAGCCACCAAAT-3') primers were used. The nucleotide sequences of these primers correspond to sequences 474-493 and 686-667 of human RBBP7 cDNA (GenBank accession number NM_002893).

Two other primers were usèd for real time RCR analysis of retinoblastoma binding protein-8 (RBBP8; DNA endonuclease) cDNA we used forward (5'-CCGAACATCCAAAAGGAAGA-3' and reverse (5'-CCTTGGCTTTTCTCTTGACG-3') primers. The nucleotide sequences of these primers correspond to sequences 1657-1676 and 18541835 of human RBBP8 cDNA (GenBank accession number NM_002894).

The amplification of beta-actin cDNA was performed by using primers: forward 5'-CGTACCACTGGCATCGTGAT-3' and reverse - 5'-GTGTTGGCGTACAGGTCTTT-3'. The expression of beta-actin mRNA was used as control of analyzed RNA quantity. The primers were received from „Sigma” (USA).

Analysis of quantitative PCR was performed by using special computer program „Differential expression calculator" and statistic analysis - in Excel program. The amplified DNA fragments were separated on $2 \%$ agarose gel and then visualized by $5 x$ Sight DNA Stain (EUROMEDEA).

\section{RESULTS}

In this study, we used human glioma cell line U87 and genetically modified variant of these cells (deficient in signaling enzyme endoplasmic reticulum - nuclei-1) to investigate an involvement of endoplasmic reticulum stress signaling system in the effect of hypoxia and glutamine or glucose deprivation on the expression of different genes coding for retinoblastoma binding proteins. To reach this goal, the cells were incubated at $37^{\circ} \mathrm{C}$ before harvesting in regular DMEM medium (control) and in the medium lacking glucose or glutamine, as well as in the hypoxic conditions during $16 \mathrm{hrs}$. Total RNA was extracted from cells, converted into complementary DNA and readily quantified by the real time polymerase chain reaction.

We have found that retinoblastoma binding proteins are expressed in the human glioma cell line U87 and the levels of expression of most studied genes are significantly depended upon the endoplasmic reticulum - nuclei-1 signaling enzyme function.

As shown in fig. 1 and 2, blocking of signaling enzyme endoplasmic reticulum - nuclei-1 function in glioma cells leads to a decrease in the expression level of mRNA of the retinoblastoma binding protein-2 (lysine-specific demethylase-5A; KDM5A), and significantly increases mRNA of the retinoblastoma binding protein-2H1 (lysine-specific demethylase$5 \mathrm{~B}$; KDM5B), as compared to control 1. At the same time, the expression levels of these mRNAs are significantly increased in both tested cell types under hypoxia and glutamine deprivation conditions. Thus, the expression levels of KDM5B mRNA are increased in hypoxic and glutamine deprivation conditions in control glioma cells much stronger than the levels of KDM5A: +67 and $+96 \%$, correspondingly, for KDM5B: +17 and $+18 \%$, correspondingly, for KDM5A, as compared to control 1. Moreover, blocking of signaling enzyme endoplasmic reticulum - nuclei-1 function in glioma cells enhances the effect of hypoxia on the expression levels of these mRNAs: KDM5A $-+75 \%$ and KDM5B $-+126 \%$.

ISSN 1996-4536 • Біологічні Студії / Studia Biologica • 2011 • Том 5/№1 • С. 57-68 


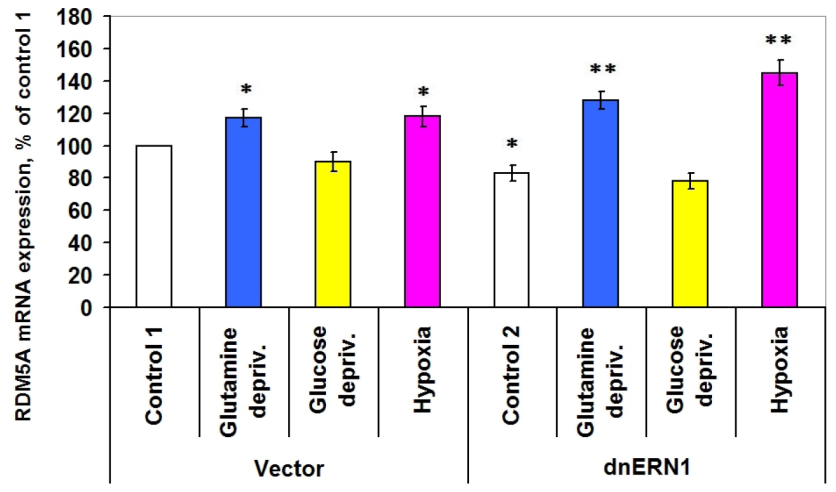

Fig. 1. Effect of hypoxia and glucose or glutamine deprivation on the expression of lysine-specific demethylase 5A (KDM5A; retinoblastoma binding protein-2) mRNA in glioma cell line U87 and its subline with a deficiency of the signaling enzyme endoplasmic reticulum - nuclei-1 (dnERN1) measured by quantitative polymerase chain reaction. Values of KDM5A mRNA expressions were normalized to beta-actin mRNA expression and represent as percent for control $(100 \%) ; \boldsymbol{n}=3$; * $-\mathrm{P}<0.05$ as compared to control $1 ;{ }^{* *}-\mathrm{P}<0.05$ as compared to control 2

Рис. 1. Вплив гіпоксії та відсутності у середовищі глутаміну або глюкози на експресію мРНК специфічної до лізину деметилази 5А (KDM5A; протеїн-2, що зв'язує ретинобластому) в клітинах гліоми лінії U87 та її сублінії з пригніченою функцією сигнального ензиму ендоплазматичний ретикулум - ядро-1 (dnERN1) методом кількісної полімеразної ланцюгової реакції. Значення експресії мPHK KDM5А нормалізували за експресією мРНК бета-актину і представляли у процентах щодо контролю $(100 \%) ; \boldsymbol{n}=3$; * $-\mathrm{P}<0,05$, порівнюючи з контролем 1 ; ** $-\mathrm{P}<0,05$, порівнюючи з контролем 2

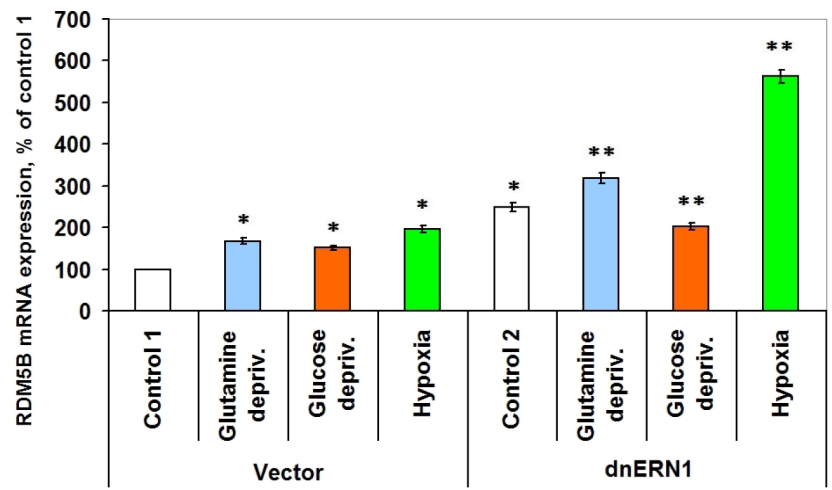

Fig. 2. Effect of hypoxia and glucose or glutamine deprivation on the expression of lysine-specific demethylase 5B (KDM5B; retinoblastoma binding protein-2H1) mRNA in glioma cell line U87 and its subline with a deficiency of the signaling enzyme endoplasmic reticulum - nuclei-1 (dnERN1) measured by quantitative polymerase chain reaction. Values of KDM5B mRNA expressions were normalized to beta-actin mRNA expression and represent as percent for control $(100 \%) ; \boldsymbol{n}=3$; * $-\mathrm{P}<0.05$ as compared to control $1 ;{ }^{* *}-\mathrm{P}<0.05$ as compared to control 2

Рис. 2. Вплив гіпоксії та відсутності у середовищі глутаміну або глюкози на експресію мРНК специфічної до лізину деметилази 5B (KDM5B; протеїн-2H1, що зв'язує ретинобластому) у клітинах гліоми лінії U87 та її сублінії з пригніченою функцією сигнального ензиму ендоплазматичний ретикулум - ядро-1 (dnERN1) методом кількісної полімеразної ланцюгової реакції. Значення експресії мРНК KDM5B нормалізували за експресією мРНК бета-актину і представляли у процентах щодо контролю (100\%); $\boldsymbol{n}=3$; * - Р < 0,05, порівнюючи з контролем 1 ; ** - Р < 0,05 порівнюючи, з контролем 2 
The results of investigation of expression levels of the retinoblastoma binding protein-4 (RBBP4), -7 (RBBP7) and -8 (RBBP8) mRNA are presented in fig. 3-5. It was

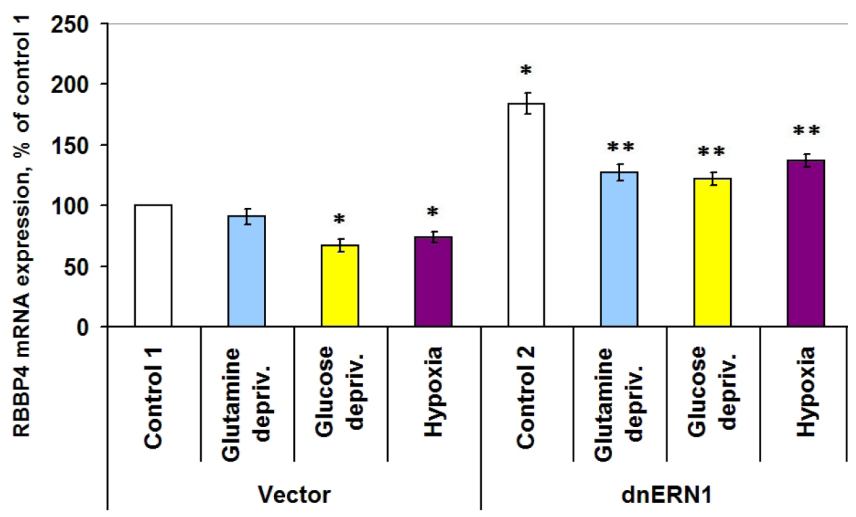

Fig. 3. Effect of hypoxia and glucose or glutamine deprivation on the expression of retinoblastoma binding protein-4 (RBBP4) mRNA in glioma cell line U87 and its subline with a deficiency of the signaling enzyme endoplasmic reticulum - nuclei-1 (dnERN1) measured by quantitative polymerase chain reaction. Values of RBBP4 mRNA expressions were normalized to beta-actin mRNA expression and represent as percent for control (100\%); $\boldsymbol{n}=3$; $^{*}-\mathrm{P}<0.05$ as compared to control 1 ; ${ }^{* *}-\mathrm{P}<0.05$ as compared to control 2

Рис. 3. Вплив гіпоксії та відсутності у середовищі глутаміну або глюкози на експресію мРНК протеїну-4, що зв'язує ретинобластому (RBBP4) у клітинах гліоми лінії U87 та її сублінії з пригніченою функцією сигнального ензиму ендоплазматичний ретикулум - ядро-1 (dnERN1) методом кількісної полімеразної ланцюгової реакції. Значення експресії мPHК RBBP4 нормалізували за експресією мРНК бета-актину і представляли у процентах щодо контролю (100 \%); $\boldsymbol{n}=3$; * - P < 0,05, порівнюючи з контролем 1 ; ** $-\mathrm{P}<0,05$, порівнюючи 3 контролем 2

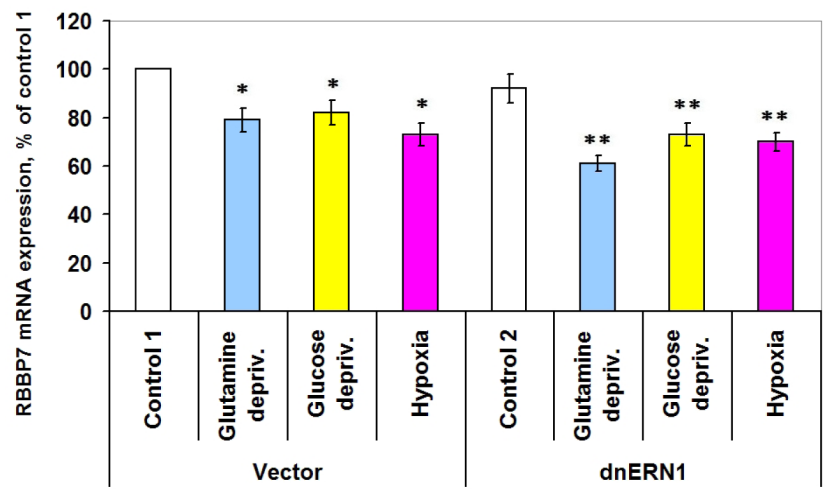

Fig. 4. Effect of hypoxia and glucose or glutamine deprivation on the expression of retinoblastoma binding protein-7 (RBBP7) mRNA in glioma cell line U87 and its subline with a deficiency of the signaling enzyme endoplasmic reticulum - nuclei-1 (dnERN1) measured by quantitative polymerase chain reaction. Values of RBBP7 mRNA expressions were normalized to beta-actin mRNA expression and represent as percent for control $(100 \%) ; \boldsymbol{n}=3 ;{ }^{*}-\mathrm{P}<0.05$ as compared to control 1 ; ${ }^{* *}-\mathrm{P}<0.05$ as compared to control 2

Рис. 4. Вплив гіпоксії та відсутності у середовищі глутаміну або глюкози на експресію мРНК протеїну-7, що зв'язує ретинобластому (RBBP7) у клітинах гліоми лінії U87 та її сублінії з пригніченою функцією сигнального ензиму ендоплазматичний ретикулум - ядро-1 (dnERN1) методом кількісної полімеразної ланцюгової реакції. Значення експресії мPHК RBBP7 нормалізували за експресією мРНК бета-актину і представляли у процентах щодо контролю (100\%); $\boldsymbol{n}=3$; * - P < 0,05, порівнюючи з контролем 1 ; ** $-\mathrm{P}<0,05$, порівнюючи 3 контролем 2 
shown that blocking of the activity of endoplasmic reticulum - nuclei-1 signaling enzyme leads to a significant induction of RBBP4 (+84\%) and RBBP8 (+50\%) mRNA expression level as compared to control cells (control 1). The exposure of cells to the medium lacking glutamine leads to a decrease in the expression levels of RBBP7 and RBBP8 mRNA in control glioma cells (-21\% and $-22 \%$, correspondingly), as well as RBBP4, RBBP7 and RBBP8 mRNA in the genetically modified cells: $-30 \%,-33 \%$ and $-33 \%$, correspondingly. However, in glucose deprivation conditions a decrease in expression levels of RBBP4 and RBBP7 mRNA was observed in both cell types: $-33 \%$ and $-18 \%$, correspondingly, in control cells and $-34 \%$ and $-21 \%$, correspondingly, in glioma cells with block of the activity of the endoplasmic reticulum - nuclei-1 signaling enzyme (fig. 3 and 4).

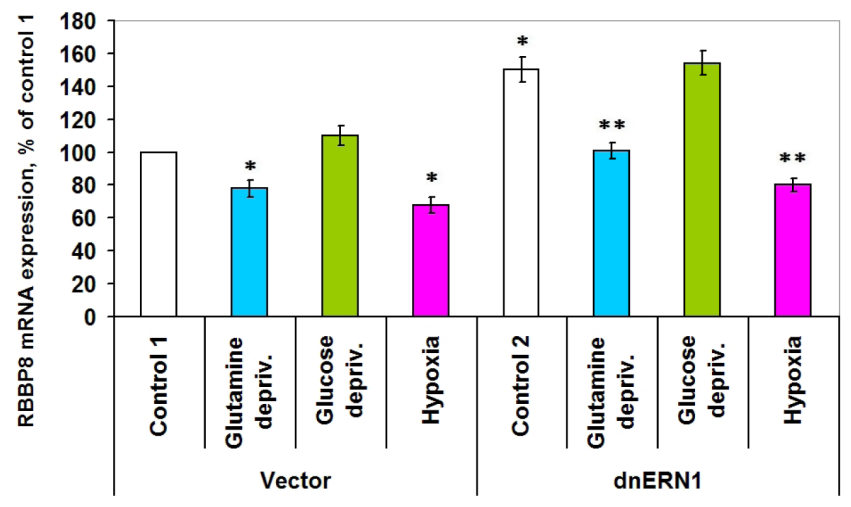

Fig. 5. Effect of hypoxia and glucose or glutamine deprivation on the expression of retinoblastoma binding protein-8 (RBBP8) mRNA in glioma cell line U87 and its subline with a deficiency of the signaling enzyme endoplasmic reticulum - nuclei-1 (dnERN1) measured by quantitative polymerase chain reaction. Values of RBBP8 mRNA expressions were normalized to beta-actin mRNA expression and represent as percent for control $(100 \%) ; \boldsymbol{n}=3$; $^{*}-\mathrm{P}<0.05$ as compared to control 1 ; ${ }^{* *}-\mathrm{P}<0.05$ as compared to control 2

Рис. 5. Вплив гіпоксії та відсутності у середовищі глутаміну або глюкози на експресію мРНК протеїну-8, що зв'язує ретинобластому (RBBP8) у клітинах гліоми лінії U87 та її сублінії з пригніченою функцією сигнального ензиму ендоплазматичний ретикулум - ядро-1 (dnERN1) методом кількісної полімеразної ланцюгової реакції. Значення експресії мРHК RBBP8 нормалізували за експресією мРНК бета-актину і представляли у процентах щодо контролю (100 \%); $\boldsymbol{n}=3$; * - P < 0,05, порівнюючи з контролем 1 ; ** $-\mathrm{P}<0,05$, порівнюючи з контролем 2

We have also shown that the exposure of glioma cells to hypoxic conditions leads to a significant decrease in the expression levels of RBBP4, RBBP7 and RBBP8 mRNA both in control and endoplasmic reticulum - nuclei-1-deficient cells: $-26 \%,-27 \%$ and $-32 \%$, correspondingly, in control glioma cells and $-26 \%,-24 \%$ and $-46 \%$, correspondingly, in genetically modified cells (fig. 3-5).

\section{DISCUSSION}

It was shown that the neovascularization process, tumor growth and cellular death processes are linked to the endoplasmic reticulum stress and its sensing and signal transduction pathways and endoplasmic reticulum - nuclei-1 in particular, because the complete blocking of the endoplasmic reticulum - nuclei-1 signaling enzyme activity had on anti-tumor effects [15-17]. Moreover, the growing tumor requires the endoplasmic reticulum stress, as well as ischemia and hypoxia which initiate the endoplasmic reticulum stress for its own neovascularization and growth, for apoptosis inhibition [15]. It is well 
known that retinoblastoma proteins, retinoblastoma binding and associated proteins, as well as E2F transcription factors, cyclins, cyclin-dependent kinases and its inhibitors participate in controling cell cycling and proliferation and are the components of endoplasmic reticulum stress system [14, 15, 18-21].

We studied two retinoblastoma proteins and a family of retinoblastoma binding or associated proteins which are ubiquitously expressed nuclear proteins: E2F transcription factors, E3 ubiquitin-protein ligase BRE1B, EP300 interacting inhibitor of differentiation, lysine-specific histone demethylases and DNA endonuclease which participate in controling cell cycling, proliferation, differentiation and apoptosis, and play an important role in controling malignant tumor growth [14, 15, 22, 23].

We have shown that blocking of the activity of signaling enzyme endoplasmic reticulum - nuclei-1 leads to a significant induction of the expression of genes encoded the tumor suppressor proteins retinoblastoma and transcription factor E2F1 which can be responsible for suppression of cell proliferation and tumor growth $[15,19,20]$. Thus, our data argue with previous results where we have shown that the complete blocking of the endoplasmic reticulum - nuclei-1 signal transduction pathway had anti-tumor effects [13, 14]. The anti-tumor effect of retinoblastoma proteins is mediated by the interaction with cyclin D1 protein and induction of its expression, as well as by binding to the E2F transcription factors and growth suppression. Moreover, active complex E2F1 with differential protein-1 (DP1) promotes apoptosis in both a p53-dependent and independent manner [21]. Thus, 2F1/DP1 induces the expression of ADP rybosylation factor (ARF), which, in turn, blocks MDM2-mediated ubiquination of p53. However, E2F1/DP1 can mediate p53dependent apoptosis in the absence of ARF through upregulation of the p53 kinase ATM and by E2F1directly binding to p53, which enhances p53 transcriptional activity.

We have also shown that complete blocking of the endoplasmic reticulum - nuclei-1 signal transduction pathway leads to an induction of the expression of several genes coding for retinoblastoma binding and associate proteins (EID1, RDM5B, RBBP4 and DNA endonuclease) that bind directly to retinoblastoma proteins to regulate cell proliferation, apoptosis and tumor growth via retinoblastoma suppressor pathways [15, 22-24]. These results also argue with anti-tumor effects of complete blocking of the endoplasmic reticulum - nuclei-1 signal transduction pathway $[13,14]$. The retinoblastoma-binding protein-4 is present in protein complexes involved in histone acetylation and has been implicated in chromatin remodeling and transcriptional repression associated with histone deacetylation. It is a part of co-repressor complex, which is an integral component of transcriptional silencing of oncogenes and suppressing of carcinogenesis. DNA endonuclease (RBBP8) was also found among several proteins that bind directly to retinoblastoma protein which regulates cell proliferation. It is also associated with BRCA1 and thought to modulate functions of BRCA1 in transcriptional regulation, DNA repair, and/or cell cycle checkpoint control [24].

However, the molecular mechanisms underlying these seemingly mutually exclusive behaviors have not been elucidated. This provides a rationale for the molecular analysis of expression signatures of invasive and growth patterns in glioma cells for a comprehensive approach of these complex mechanisms. Bifunctional transmembrane signaling enzyme endoplasmic reticulum - nuclei-1 is a major proximal sensor of the unfolded protein response, it participates in the early cellular response to the accumulation of misfolded proteins in the endoplasmic reticulum under both physiological and pathological conditions and in malignant tumors, in particular $[15,17]$. Therefore, we studied the expression of several genes coding for the retinoblastoma proteins and retinoblastoma binding or associated proteins in glioma cells lacking the activity of endoplasmic reticulum - nuclei-1 signaling enzyme for the evaluation of these genes responsibility upon the endoplasmic

ISSN 1996-4536 • Біологічні Студії / Studia Biologica • 2011 • Том 5/№1 • С. 57-68 
reticulum - nuclei-1 signaling enzyme function. The results of this investigation clearly demonstrate that the expression levels of retinoblastoma proteins and most retinoblastoma binding or associated proteins. They form a complex with and function as a part of co-repressor complexes, are increased in glioma cells without endoplasmic reticulum - nuclei-1 signaling enzyme function which is responsible for tumor growth. These data correlate with anti-tumor effects of this ERN1 block [15, 17].

In this study we have also shown that the exposure of cells to hypoxia and their culturing in the medium lacking glutamine or glucose leads to a decrease in the expression level of mRNAs coding for retinoblastoma like-1 protein and most of retinoblastoma binding proteins in control and endoplasmic reticulum - nuclei-1-deficient glioma cells. However, the expression levels of lysine-specific demethylase 5A (KDM5A; RBBP2) and 5B (KDM5B; $\mathrm{RBBP} 2 \mathrm{H} 1$ ) mainly are increased in control and genetically modified glioma cells exposed to hypoxia and to medium lacking glutamine. This phenomenon could be due to an induction of endoplasmic reticulum stress in the hypoxic and nutrient starvation conditions and to result in suppression of anti-proliferative proteins via endoplasmic reticulum stress signaling systems. It is possible that the expression levels of genes, coding for retinoblastoma proteins and most of retinoblastoma binding proteins, depends not only on the endoplasmic reticulum - nuclei-1 signaling enzyme but also on two other signaling pathways: PERK (PKR-like endoplasmic reticulum kinase) and ATF6 (activating transcription factor 6) $[4,17]$.

Hypoxia and ischemic conditions (incubation in the medium lacking glucose or glutamine) induce endoplasmic reticulum stress, which are necessary for tumor neovascularization and growth. We have studied the expression of retinoblastoma-related genes which play a significant role in the control of cell cycling, proliferation and apoptosis and are the component of unfolded protein response and its major sensor - endoplasmic reticulum - nuclei-1 signaling pathway $[2,9,15]$. Our results demonstrated that there is similarity in the expression patterns of different retinoblastoma-related genes under endoplasmic reticulum stress induced by hypoxia and ischemic conditions (glucose or glutamine deprivation), because these genes are responsible for activation of tumor growth in endoplasmic reticulum stress. At the same time, there are some differences in the expression patterns of these genes growing under hypoxia or ischemic conditions which possibly connected with specific reaction of cells on different agent. Moreover, both glucose and glutamine deprivation conditions are parts of nutrient deprivation but glutamine is not only amino acid, it is very important of brain cell signaling [15].

The major finding reported here is that the expression of most tested genes that encode the retinoblastoma proteins and most of retinoblastoma binding proteins are dependent on function of the endoplasmic reticulum - nuclei-1 signaling enzyme - both in normal and hypoxic or nutrient deprivation conditions. It is possible that the retinoblastoma proteins and most of retinoblastoma binding or associated proteins participate in adaptive response of cells to endoplasmic reticulum stress associated with ischemia or nutrient deprivation. However, detailed molecular mechanisms of regulation of genes coding for the retinoblastoma proteins and retinoblastoma binding or associated proteins by the endoplasmic reticulum - nuclei-1 signaling system under ischemic and glutamine or glucose deprivation conditions is very complex and needs further study.

\section{CONCLUSIONS}

Results of these investigations demonstrated that the expression of genes encoding the retinoblastoma proteins and most retinoblastoma binding or associated proteins in glioma cells is regulated by hypoxia, glutamine or glucose deprivation and significantly 
depends upon the activity of signaling enzyme endoplasmic reticulum - nuclei-1. Thus, the retinoblastoma proteins and most retinoblastoma binding or associated proteins might participate in cell adaptive response to endoplasmic reticulum stress associated with hypoxia and glutamine or glucose deprivation in glioma cell line U87, as well as in subline lacking the activity of signaling enzyme endoplasmic reticulum - nuclei-1.

1. Aragón T., van Anken E., Pincus $D$. et al. Messenger RNA targeting to endoplasmic reticulum stress signalling sites. Nature, 2009; 457 (7230): 736-740.

2. Bi M., Naczki C., Koritzinsky M. et al. ER stress-regulated translation increases tolerance to extreme hypoxia and promotes tumor growth. EMBO Journal, 2005; 24(19): 3470-3481.

3. Blais J.D., Filipenko V., Bi M. et al. Transcription factor 4 is translationally regulated by hypoxic stress. Molecular and Cellular Biology, 2004; 24: 7469-7482.

4. Fels D.R., Koumenis C. The PERK/elF2a/ATF4 module of the UPR in hypoxia resistance and tumor growth. Cancer Biology \& Therapy, 2006; 5(7): 723-728.

5. Luo D., He Y., Zhang H., Yu L. et al. AIP1 Is Critical in Transducing IRE1-mediated Endoplasmic Reticulum Stress Response. The Journal of Biological Chemistry, 2010; 283 (18): 11905-11912.

6. Korennykh A.V., Egea P.F., Korostelev A.A. et al. The unfolded protein response signals through high-order assembly of Ire1. Nature, 2009; 457(7230): 687-693.

7. Romero-Ramirez L., Cao H., Nelson D. et al. XBP1 is essential for survival under hypoxic conditions and is required for tumor growth. Cancer Research, 2004; 64: 5943-5947.

8. Lin J.H., Li H., Yasumura D. et al. IRE1 signaling affects cell fate during the unfolded protein response. Science, 2007; 318: 944-949.

9. Hollien J., Lin J.H., Li H. et al. Regulated Ire1-dependent decay of messenger RNAs in mammalian cells. Journal of Cell Biology, 2009; 186(3): 323-331.

10. Acosta-Alvear D., Zhou Y., Blais A. et al. XBP1 controls diverse cell type- and condition-specific transcriptional regulatory networks. Molecular Cell, 2007; 27: 53-66.

11. Han D., Upton J.-P., Hagen A. et al. A kinase inhibitor activates the IRE1alpha RNase to confer cytoprotection against ER stress. Biochemical Biophysical Research Communications, 2008; 365: 777-783.

12. Greenman C., Stephans P., Smith $R$. et al. Patterns of somatic mutation in human genomes. Nature, 2007; 446: 153-158.

13. AufG., Jabouille A., Guérit $S$. et al. A shift from an angiogenic to invasive phenotype induced in malignant glioma by inhibition of the unfolded protein response sensor IRE1. Proceedings of the National Academy of Sciences of the U.S.A, 2010; 107(35): 15553-15558.

14. Drogat B., Auguste P., Nguyen D.T. et al. IRE1 signaling is essential for ischemia-induced vascular endothelial growth factor-A expression and contributes to angiogenesis and tumor growth in vivo. Cancer Research, 2007; 67 (14): 6700-6707.

15. Moenner M., Pluquet O., Bouchecareilh M., Chevet E. Integrated endoplasmic reticulum stress responses in cancer. Cancer Research, 2007; 67(22): 10631-10634.

16. Guan $D$., $X u$ Y., Yang M. et al. N-acetyl cysteine and penicillamine induce apoptosis via the ER stress response-signaling pathway. Molecular Carcinogenesis, 2010; 49 (1): 68 -74.

17. Saito A., Ochiai K., Kondo S. et al. Endoplasmic Reticulum Stress Response Mediated by the PERK-elF2-ATF4 Pathway Is Involved in Osteoblast Differentiation Induced by BMP2. The Journal of Biological Chemistry, 2011; 286 (6): $4809-4818$.

18. Maddika S., Ande S.R., Panigrahi S. et al. Cell survival, cell death and cell cycle pathways are interconnected: implications for cancer therapy. Drug Resistance Updates, 2007; 10(1-2): 13-29.

19. Sharma A., Yeow W.S., Ertel A. et al. The retinoblastoma tumor suppressor controls androgen signaling and human prostate cancer progression. Journal of Clinical Investigation, 2010; 120 (12): 4478-4492.

20. Liao C.C., Tsai C.Y., Chang W.C. et al. RB.E2F1 complex mediates DNA damage responses through transcriptional regulation of ZBRK1. The Journal of Biological Chemistry, 2010; 285(43): 33134-33143.

ISSN 1996-4536 • Біологічні Студії / Studia Biologica • 2011 • Том 5/№1 • С. 57-68 
21. Gurtner A., Fuschi P., Martelli F. et al. Transcription factor NF-Y induces apoptosis in cells expressing wild-type p53 through E2F1 upregulation and p53 activation. Cancer Research, 2010; 70(23): 9711-9720.

22. Lopez-Bigas N., Kisiel T.A., Dewaal D.C. et al. Genome-wide analysis of the H3K4 histone demethylase RBP2 reveals a transcriptional program controlling differentiation. Molecular Cell, 2008; 31(4): 520-530.

23. Hayami S., Yoshimatsu M., Veerakumarasivam A. et al. Overexpression of the JmjC histone demethylase KDM5B in human carcinogenesis: involvement in the proliferation of cancer cells through the E2F/RB pathway. Molecular Cancer, 2010; 9: 59.

24. Salles D., Mencalha A.L., Ireno I.C. et al. BCR-ABL stimulates mutagenic homologous DNA double-strand break repair via the DNA-end-processing factor CtIP. Carcinogenesis, 2011; 32(1): 27-34.

25. Kulinich A.O., Minchenko D.O., Maslak A.S. et al. Fibronectin-1 expression in lymphocytes of patients with erythremia disease. Ukrainian Biochemical Journal, 2010; 82(4): 53-59.

\title{
ВПЛИВ ГІПОКСІї, ВІДСУТНОСТІ ГЛУТАМІНУ АБО ГЛЮКОЗИ У СЕРЕДОВИЩІ НА ЕКСПРЕСІЮ ГЕНІВ РЕТИНОБЛАСТОМИ ТА ПОВ'ЯЗАНИХ З РЕТИНОБЛАСТОМОЮ ГЕНІВ У КЛІТИНАХ ГЛІОМИ
}

\author{
Д. О. Мінченко ${ }^{1,2,3}$ Л. Л. Карбовський', С. В. Даниловський', М. Моне \\ ${ }^{1}$ /нститут біохімії ім. О. В. Палладіна НАН України, вул. Леонтовича, 9, Київ 01601, Україна \\ ${ }^{2}$ Національний медичний університет ім. О. О. Богомольця, \\ бульв. Шевченка, 13, Київ 01601, Україна \\ 3INSERM U920 Лабораторія молекулярних механізмів ангіогенезу, \\ Університет Бордо 1, Таленс, Франція \\ e-mail: ominchenko@yahoo.com
}

Гіпоксія та ішемія, як і стрес ендоплазматичного ретикулуму, що індукується цими чинниками, $є$ необхідними факторами росту злоякісних пухлин та їх неоваскуляризації. Ми вивчали вплив блокади основного сигнального ензиму стресу ендоплазматичного ретикулуму - ендоплазматичний ретикулум - ядро-1 на експресію декількох залежних від ретинобластоми генів, що відіграють суттєву роль у контролі клітинного циклу, проліфрерації та апоптозу, у клітинах гліоми лінії U87. Ми також вивчали вплив гіпоксії та умов ішемії (відсутності у середовищі глюкози або глутаміну) на експресію цих генів у контрольних клітинах гліоми та сублінії цих клітин із пригніченою функцією сенсорно-сигнального ензиму ендоплазматичний ретикулум - ядро-1. Встановлено, що блокада сигнального ензиму ендоплазматичний ретикулум - ядро-1 приводить до збільшення рівня експресії декількох генів протеїнів, що зв'язуються з ретинобластомою: RBBP2H1 (RDM5B), RBBP4 та RBBP8. Більше того, рівні експресії більшості досліджуваних генів суттєво зменшуються за умов відсутності у середовищі глюкози або глутаміну як у контрольних, так і в дефіцитних за ензимом ендоплазматичний ретикулум - ядро-1 клітинах гліоми, але рівні експресії RBBP2H1 та RBBP2 (RDM5A) мРНК збільшуються за відсутності у середовищі глутаміну в обох досліджуваних типах клітин. Встановлено, що за умов гіпоксії рівні експресії RBBP4, RBBP7 та RBBP8 зменшуються, a RBBP2 та RBBP2H1 збільшуються також в обох досліджуваних типах клітин. Отже, експресія генів ретинобластоми та більшості пов'язаних з нею генів залежить від фрункції сигнального ензиму ендоплазматичний ретикулум - ядро-1 як за нормальних умов, так і за умов гіпоксії та ішемії. 
Ключові слова: експресія мРHК, RBBP4, RBBP7, RBBP8, RBBP2, RBBP2H1, клітини гліоми, ендоплазматичний ретикулум - ядро-1, гіпоксія, відсутність глюкози або глутаміну.

\title{
ВЛИЯНИЕ ГИПОКСИИ И ОТСУТСТВИЯ ГЛЮТАМИНА ИЛИ ГЛЮКОЗЫ В СРЕДЕ НА ЭКСПРЕССИЮ ГЕНОВ РЕТИНОБЛАСТОМЫ И СВЯЗАНЫХ С РЕТИНОБЛАСТОМОЙ ГЕНОВ В КЛЕТКАХ ГЛИОМЫ
}

\author{
Д. А. Минченко, \\ ${ }^{1}$ Институт биохимии им. А.В. Палладина НАН Украины \\ ул. Леонтовича, 9, Киев 01601, Украина \\ ${ }^{2}$ Национальный медицинский университет им. А. А. Богомольца, \\ бульв. Шевченко, 13, Киев 01601, Украина \\ 3INSERM U920 Лаборатория молекулярных механизмов ангиогенеза, \\ Университет Бордо 1, Таленс, Франция \\ e-mail: ominchenko@yahoo.com
}

Протеин ретинобластомы и протеины, связывающиеся с ним, играют важную роль в контроле клеточного цикла, пролиферации и апоптоза. Гипоксия и ишемия, как и стресс эндоплазматического ретикулума, которые индуцируются этими воздействиями, являются необходимыми факторами роста злокачественных опухолей и их неоваскуляризации. Мы изучали влияние блокады основного сигнального энзима стресса эндоплазматического ретикулума - эндоплазматический ретикулум ядро-1 на экспрессию нескольких зависимых от ретинобластомы генов в клетках глиомы линии U87. Мы также изучали влияние гипоксии и условий ишемии (отсутствия в среде глюкозы или глютамина) на экспрессию этих генов в контрольных клетках глиомы и сублинии этих клеток с угнетенной функцией сенсорно-сигнального энзима эндоплазматический ретикулум - ядро-1. Установлено, что блокада сигнального энзима эндоплазматический ретикулум - ядро-1 приводит к увеличению уровня экспрессии нескольких генов протеинов, которые связываются с ретинобластомой: RBBP2H1 (RDM5B), RBBP4 и RBBP8. Более того, уровни экспрессии большинства изученных нами генов существенно изменяются в условиях отсутствия в среде глюкозы или глютамина как в контрольных, так и в дефицитных по энзиму эндоплазматический ретикулум - ядро-1 клетках глиомы. Однако уровни экспрессии RBBP2H1 и RBBP2 (RDM5A) мРНК увеличиваются при отсутствии в среде глютамина в обоих типах использованных в исследовании клеток. Установлено, что уровни экспрессии RBBP4, RBBP7 и RBBP8 снижаются, a RBBP2 и RBBP2H1 увеличиваются при гипоксии также в обоих исследованных типах клеток. Таким образом, экспрессия генов ретинобластомы и большинства связанных с ней генов зависит от функции сигнального энзима эндоплазматический ретикулум - ядро-1 как в нормальных условиях, так и в условиях гипоксии и ишемии.

Ключевые слова: экспрессия мРHК, RBBP4, RBBP7, RBBP8, RBBP2, RBB$\mathrm{P} 2 \mathrm{H} 1$, клетки глиомы, гипоксия, эндоплазматический ретикулум - ядро-1, отсутствие глюкозы или глютамина в среде.

Одержано: 31.03.2011

ISSN 1996-4536 • Біологічні Студії / Studia Biologica • 2011 • Том 5/№1 • С. 57-68 